folk/ed. Derg, 2020; 26(1): 55-72

DOI: 10.22559/folklor.1138

\title{
Kültürel Çeşitliliğin Mısır Unu Kullanımına Etkisi: Kartepe Örneğinde Mısır Ununun Kimliksel Dönüşümü
}

\author{
Cultural Diversity Effect of Corn Flour on Usage: \\ Ethnic Variation of Corn Flour in Kartepe Sample
}

\section{Ersin Uğurkan* Ömür Alyakut ${ }^{* *}$}

$\ddot{\mathbf{O} z}$

$\mathrm{Bu}$ çalışmanın amacı kültürel kimliklerin mısır unuyla yapılan yemekleri nasıl şekillendirdiğini ortaya koymak ve bu farklılığın kimlik ile özdeş hale gelmesini irdelemektir. Bu kapsamda kültürel çeşitliliğin gastronomide nasıl değişkenlik gösterdiği de vurgulanmaya çalışılmıştır.

Çalışmanın evrenini Kocaeli ili Kartepe ilçesi, örneklemini Kartepe ilçesinin sekiz mahallesi oluşturmuştur. Bu mahallelerde yaşayan Gürcü, Abhaz, Çerkez (Adige), Laz, Manav ve Muhacir kökenli kadınlar arasından 50 yaş ve üzeri yirmi dört kadın amaçsal örneklem yöntemiyle çalışma grubu için seçilmiştir. Seçilen kadınlara yarı yapılandırılmış görüşme formu eşliğinde sorular sorulmuştur.

Araştırma sonucunda Kartepe ilçesindeki kültürel çeşitliliğin mısır unu kullanımına yansıdığı ve mısır unu ile yapılan yemeklerin kimliklerle özdeş olarak farklı üretim biçimlerine yol açtığı tespit edilmiştir. Bu uygulamaların kimlikler üzerinden yemekleri daha belirleyici ve görünür kıldığı saptanmıştır. Ayrıca mısır unu ile yapılan

Geliş tarihi (Received): 22 Haziran 2019 - Kabul tarihi (Accepted): 05 Ekim 2019

Öğr. Gör., Kocaeli Üniversitesi Kartepe Turizm MYO. eugurkan@gmail.com. ORCID ID: 0000-0001-58473925.

** Öğr. Gör. Dr., Kocaeli Üniversitesi Kartepe Turizm MYO. omalyakut@gmail.com. ORCID ID: 0000-0002-5517-1881. 
bazı yemeklerin çok bilinmesine rağmen bazılarının neredeyse unutulmaya yüz tuttuğu bazılarının ise başka kültüre addedildiği tespit edilmiştir. Sonuç olarak yörede yapılan yemeklerin kültürel kimliklerin dinamik kalmasına ve korunmasına katk1 sağladığı ortaya koyulmuştur. Bu yönüyle çalışma yemek, kültür ve kimlik ilişkisini ortaya koyması ve alana katkı sağlaması bakımından önem arz etmektedir.

Anahtar sözcükler: Kartepe, kültürel çeşitlilik, kimlik, mısır unu, yemek

\begin{abstract}
The aim of this study is to reveal how cultural identities change the meals made with corn flour. It also examines the integration of this different food culture with identity. In this context, it is attempted to emphasize how cultural diversity varies in gastronomy.

The population of the study consisted of Kartepe district of Kocaeli province and eight streets of Kartepe district. Twenty-four women aged 50 and over were selected from the Georgian, Abkhazian, Circassian (Adyge), Laz, Manav (LocalTurkish) and Muhacir (Migrants) women living in these neighborhoods through purposeful sampling method. The selected women were asked questions by using a semi-structured interview form.

As a result of the research, it was found that cultural diversity in Kartepe district is reflected in the use of corn flour and the meals made with corn flour lead to different production styles identical to the ethnic backgrounds. It has been determined that these practices make the dishes more identifiable and visible through identities. In addition, although some dishes made with corn flour are well known, some are almost forgotten and some are considered to be from other cultures. As a result, it has been shown that the food made in the region contributes to the preservation and dynamics of cultural identities. In this respect, the study is important and contributes to the field in terms of revealing the relationship between food, culture and identity.
\end{abstract}

Keywords: Kartepe, cultural diversity, identity, corn flour, food

\title{
Giriş
}

Yemek, grup aidiyetini tanımlayan güçlendiren '"estetik, kültürel ve göstergebilimsel kod" olarak iş gören, sembolik bir işleve sahiptir. İnsanların kimlikle ilgili konularla ilk karşılaşmaları damak tatları vasıtasıyla olmuştur. İnsanlar büyüdükleri yer, ait oldukları gruplar ve yaşadıkları toplumsal mekânlarla bağlantılı olduklarından yedikleri yemek kim olduklarına yönelik bilgiyi de aktarmaktadır. Damak tadı, yemek tercihi ve kimlikler arasında güçlü bir bağlantı bulunmaktadır (Ichijo ve Ranta, 2018: 37- 39).

Kocaeli ili Kartepe ilçesinin demografik yapısı göçler nedeniyle kültürel bir mozaiği andırmaktadır. Kartepe’ye ilk göçler (1864) Çerkez (Adige) ve Abhaz göçleridir. İkincisi Osmanlı Rus Harbiyle (1877-1878) birlikte Kuzey Kafkasya'dan ve Acara Özerk bölgesi olan Gürcistan'dan 
olan göçlerdir. Balkan Savaşları (1912-1913) ile birlikte ise Rumeli'den Türk kökenli Muhacirler ilçeye yerleşmiştir. Ayrıca bölgenin yerlileri olan Manavlar da burada yaşamaktadır. Bu şekilde ilçenin etnik dokusu Manav-Çerkez (Adige)-Abhaz-Gürcü-Laz ve Muhacir olmak üzere kültürel çeşitlilik göstermiştir (Karpat, 2010: 35; Ulugün, 2014, 1276; McCarthy, 1998: 5).

$\mathrm{Bu}$ kültürel çeşitlilik, yörenin gastronomisine de yansımıştır. Yörenin gastronomi değerlerinden olan mısır unuyla yapılan yemekler dikkat çekmiştir. Kültürel kimliklerin mısır unuyla yapılan yemekleri nasıl şekillendirdiğini ortaya koymak amaçlanmıştır. Nitel araştırma olarak planlanan çalışmada, yarı yapılandırılmış görüşme formu kullanılmış, kültürel kimlikleri temsilen 50 yaş ve üzeri yirmi dört kadın amaçsal örneklem yöntemiyle seçilmiştir. Verilerin analizinde içerik analizi kullanılmış, sonuçlar betimsel analizle yorumlanmıştır.

\section{Kimlik, kültür, yemek ilișkisi}

Kimlik kelimesi, aynılığı ve sürekliliği kapsayan Latince "idem” kökünden gelmiştir. Türkçe' de kimlik, "kim” soru kökünden türetilmiş olup aynı şekilde zorunlu bir aidiyeti aynı olmayı, hangi kişi olmayı ifade etmektedir. Kimlik var olmak için farklılığa gereksinim duymakta ve kendi kesinliğini güven altına almak için farklılığı ötekiliğe dönüştürmektedir (Dalbay, 2018: 162). Özellikle kimliğimiz ile ilgili düşünceler aslında diğer kişilerin bizim hakkımızda ne düşündüklerinin bir yansımasıdır (Bilgin ve Oksal, 2018: 84).

Kimliğin oluşmasında kültür kritik bir öneme sahiptir. Kültür bireyin kendini düşünmesi ve insan olarak tanımlamasıdır (Bilgin ve Oksal, 2018: 86). Nesnelerden, düşünce biçimlerinden ve davranışlardan oluşan bir kalıttır. Bu kalıt bir topluluğa ve üyelerine kimlik vermektedir (Bourse ve Yücel, 2017: 129).

Kültürel kimlik bireyin kendisini millet, etnisite, 1rk, cinsiyet ve din gibi çeşitli kültürel kategorilerden oluşan belirli bir grup ile tanımlaması veya ona ait olduğunu hissetmesi anlamına gelmektedir. Kültürel gelenekler; miras, dil, estetik, kurallar ve örfler gibi kolektif bilginin paylaşılma sürecinde oluşmakta, devamlılığını sürdürmektedir (Huseh ve Chen, 2017). Tarihsel süreç içinde yok olmaya karşı direnen toplumlar güçlerini kültürel kimliklerinden almışlardır (Bilgin ve Oksal, 2018: 86). Hall’a göre kültürel kimlik iki görüşle açıklanabilir. İlki; tek bir kültür olarak diğer kültürleri içinde barındırır ve o toplumu 'bir halk" haline dönüştürür. İkincisi bireylerde benzer olan noktaları kabul eder ancak bireyleri ayıran farklılıkların da olduğunu belirterek aslında bu farklılıkların ne olduğumuzu belirlediğini açıklar. Bu ikinci anlam "var olma" kadar bir "olma” meselesidir. Geçmişe aitlik gibi geleceğe de aitliktir. Kültürel kimliklerin geldiği bir yer, tarih, zaman ve başlangıç noktası bulunmaktadır (Huvaj, 2005). Bütün kültürel kimlikler, ötekinin varlığını ve kültürel pratiklerini kabul ederek tanımlanmaktadır (Huseh ve Chen, 2017).

Yemek bireysel ve toplumsal yönleri olan kültürel bir unsurdur. İnsan fizyolojik olarak yemekle doğrudan ilgili olduğu gibi sosyal olarak da yaşadığı kültürün etkisinde bir yemek kültürüne sahiptir. Bu bakımdan yemeklerde göçebe ve yerleşik biçimde farklılıklar görülmekte, bu farklılık yeme kültürüne önemli ölçüde yansımaktadır (Beşirli, 2010: 160-161). Kültürlerin farklılığını gösteren en karakteristik ürün yiyeceklerdir. Türk mutfağı gibi isimlendirilen yemek kültürü, kültür içerisinde bir parçadan ibarettir (Abdulrezzak, 2016: 2). 
Kültürel kod olan yemek, ideoloji ile birlikte kimliği ifade etmektedir. İdeoloji, ait olduğumuz toplumsal kimliğin yapısında bulunan ana faktörlerden biri olarak bireyleri birbirinden ayırarak sınırlarını belirlemektedir. Yemek türleri, isimleri, malzemeler- ekipmanlar, geçmişe göndermeler ve daha birçok şey kimlik ve kültürle ilgili olduğundan ulusal mutfakların şekillenmesinde de kullanılmaktadır (Fırat, 2014: 137). Mutfaklar, yiyeceklerle bir bölgenin kimliğini, insanların yaşamını ve kişiliklerini yansıtmaktadır. Mutfaklar doğru tanımlandığında bölge ve içerdiği insanlar da doğru tanımlanmaktadır (Gürs, 2013). Ulusal mutfakların oluşmasında etnik mutfaklar önemli rol oynamaktadır (Ichijo ve Ranta, 2018: 13). Etnik grubun kimliği: Tarihsel, çevresel, sosyal birçok farklı unsur üzerine inşa edilebilmektedir. Bir mutfağa ilişkin semboller etnik özellik kalıplarıyla aynı sistemin parçalarıdır. Türkiye'de etnik olarak anılan bazı yemek adları vardır. Bu tür adlandırma (Laz böreği, Çerkez tavuğu vb.) etnik sınırlarla aidiyet ilişkisinin sadece insanlar için değil, onun elinde şekillenen maddi çevre için de geçerli olduğunu göstermektedir (F1rat, 2014: 138).

\section{Misir ve misir unu}

Mısır, binlerce yıldır tarımı yapılan birkaç ender bitkiden biridir. Anavatanı Amerika k1tası olup buradan dünyaya yayılmıştır. New Mexico'da yapılan arkeolojik kazılarda bulunan mısır taneleri ve mısır koçanı parçalarının yaklaşık 5000 yıllık, Mexico City'de yapılan arkeolojik kazılarda (1954) bulunan mısır çiçek tozlarının ise yaklaşık 7000 yıllık olduğu belirlenmiştir (Babaoğlu, 2019).

Göçler, farklı kültürel ürünlerin tanınmasına yol açmıştır. Amerika'nın keşfinden sonra (1493) Avrupa'ya getirilen mısır, İspanya'da ekilmiştir. Mısır buradan İtalya ile Osmanlı Devleti'ne ulaşmış ve Avrupa'nın gözde tüketim maddesi olmuştur. Ardından Uzakdoğu ve Çin'e yerleşmiştir. Balkanlarda ve çiftliklerde ekilmesiyle (XVIII. yy.) ticarî nitelik kazanmıştır. Almanlar ve Macarlar mısırı Osmanlı Devleti'nde tanıdıktan sonra ülkelerine götürmüşlerdir. Böylece Avrupa'ya yayılmış ve Fransa'da “Türkiye buğdayı” olarak anılmıştır. Adapazarı'ndan Batum'a uzanan sahil boyunda ve bazı iç kesimlerde mısır üretimi (XIX. yy.) yaygınlaşmıştır (Kuzucu, 2006: 116-118).

Amerika'da ilk mısır ununun üretildiği ve mısır ekmeği yapıldığı bilinmektedir (Şener, 2019). Kafkasya'dan Anadolu'ya gelen Muhacirlerin temel besin maddelerinden biri misırdır. Karadeniz' in doğusunda Lazlar, Gürcüler ve Çerkezlerin (Adige) mutfağında mısır unu temel besindir (Kuzucu, 2006: 118). Bu nedenle misır unu, bu coğrafyalarda ekmek üretimi başta olmak üzere, hamur işlerinde, et ve balık pişirmede, çorba ve kek yapımında önemli bir yere sahiptir (Öksüz Yolkolu, 2016: 152- 160).

\section{Araştırma yöntemi}

Bu çalışma kültürel kimliklerde mısır unu kullanım farklılığını ortaya koymak amacıyla yapılmıştır. Ortaya çıkan kullanım farklılığının kimlik ile nasıl özdeş hale geldiği ve kültürel kimliklerin gastronomide nasıl değişkenlik gösterdiği de vurgulanmaya çalışılmıştır.

Çalışmada nitel araştırma yöntemi ve olgubilim deseni tercih edilmiştir. Olgubilim farkında olduğumuz ancak derinlemesine ve ayrıntılı bir anlayışa sahip olmadığımız olgulara odaklanmaktadır (Yıldırım ve Şimşek, 2018: 69). 
Çalışmanın evrenini Kocaeli ili Kartepe ilçesi, örneklemini Kartepe ilçesinin sekiz mahallesi (Maşukiye, Derbent, Suadiye, Uzuntarla, Eşme, Şirinsulhiye, Karatepe, Ketenciler) oluşturmuştur. Bu mahallelerde farklı kültürel gruplar yoğun olarak yaşadığından, örneklemin evreni temsil etme gücü yüksektir. Çalışmada öncelikle mahalle muhtarları ile görüşülmüş ve kültürel grupların her birini temsil edebilecek, konu hakkında bilgi sahibi 50 yaş ve üzeri yirmi dört kadın amaçsal örneklem yöntemiyle seçilmiştir. Çalışmada maksimum çeşitlilik örneklemesi kullanılmıştır. Farklı tipteki örneklemlerin alınmasındaki amaç, genelleme yapmak değil aksine paylaşılan ya da ayrılan durumların olup olmadığını saptamaktır (Baltacı, 2018: 249). Örneklem kapsamına alınan kadınların yaş ortalaması 64'tür. Her kadından 4 tanesi farklı kültürel kimliğe aittir. Kadınlardan 7'si okuryazar değil, 17'si ilkokul mezunudur. Katılımcılar K1, K2 ... olarak kodlanmıştır. Tablo 1'de katılımcıları tanımlayıcı bilgiler verilmiştir. Katılımcıların tamamının cinsiyeti kadın, mesleği ev hanımı olduğundan tabloda cinsiyet ve mesleğe ait bilgilere yer verilmemiştir.

Seçilen kadınlarla yarı yapılandırılmış görüşme formu eşliğinde 45-50 dk. süren yüz yüze görüşmeler yapılmıştır. Görüşmelerde ses ve görüntü kayıtları alınmıştır. Görüşmeler sırasında elde edilen bilgilerin tekrar edilmeye başlaması ve doygunluğa ulaşması (Miles ve Hubermen, 1994) katılımcı sayısının yeterli olduğunu göstermiştir. Mülakat soruları için öncelikle literatür taraması yapılmış ardından iki uzman görüşü alınmıştır. Sorular aşağıdaki gibidir.

- Kültürel kimliğiniz nedir? Mısır unuyla yapılan hangi yemek kimliğinizle özdeştir?

- Mısır unuyla yaptığınız yemekler diğer kültürlerde farklılık göstermekte midir? Gösteriyorsa bu farklılıklar nelerdir?

- Yemeklerinizin grup aidiyetine ve yörenin yemek kültürüne katkısı var mıdır? Varsa nelerdir?

Çalışmanın geçerlilik ve güvenirliliğini artırmak için iki uzman görüşüne başvurulmuş, çalışmanın ayrıntıları ve bulguları uzmanlara aktarılarak değerlendirmeleri istenmiştir. Geri bildirim sonucu düzeltmeler yapılarak çalışmaya son şekli verilmiştir. Böylece araştırmanın niteliği artırılarak geçerlik ve güvenirliğe katkı sağlanmıştır (Yıldırım ve Şimşek, 2018).

Tablo 1: Katılımcıları Tanımlayıc1 Bilgiler

\begin{tabular}{|c|c|c|c|}
\hline Katılımeı & Kültürel Kimlik & Yaş & Eğitim \\
\hline K1 & \multirow{4}{*}{ Manav } & 65 & Okur Yazar Değil \\
\hline K2 & & 57 & \multirow{4}{*}{ İlkokul } \\
\hline $\mathrm{K} 3$ & & 51 & \\
\hline $\mathrm{K} 4$ & & 63 & \\
\hline K5 & \multirow{4}{*}{ Muhacir } & 52 & \\
\hline K6 & & 75 & Okur Yazar Değil \\
\hline K7 & & 70 & \multirow{3}{*}{ İlkokul } \\
\hline K8 & & 69 & \\
\hline K9 & \multirow{4}{*}{ Gürcü } & 64 & \\
\hline K10 & & 80 & \multirow{2}{*}{ Okur Yazar Değil } \\
\hline K11 & & 78 & \\
\hline K12 & & 65 & \\
\hline
\end{tabular}




\begin{tabular}{|c|c|c|c|}
\hline K13 & \multirow{4}{*}{ Abhaz } & 54 & \multirow{9}{*}{ İlkokul } \\
\hline K14 & & 59 & \\
\hline K15 & & 61 & \\
\hline K16 & & 60 & \\
\hline K17 & \multirow{4}{*}{ Laz } & 67 & \\
\hline $\mathrm{K} 18$ & & 57 & \\
\hline K19 & & 54 & \\
\hline K20 & & 63 & \\
\hline K21 & \multirow{4}{*}{ Çerkez (Adige) } & 61 & \\
\hline K22 & & 68 & \multirow{3}{*}{ Okur Yazar Deği } \\
\hline K23 & & 72 & \\
\hline K24 & & 76 & \\
\hline
\end{tabular}

Çalışmanın tasarlanmasında verilerin daha önceden belirlenen kategorilere göre özetlenmesini ve yorumlanmasını temel alan betimsel analiz kullanılmıştır. Çalışma verilerinin analizi için Wolcott (1994)'un önerdiği üç yol kullanılmıştır. Buna göre; toplanan verinin özgünlüğünün korunabilmesi için katılımcıların söylemlerine doğrudan alıntılar yapılması ve araştırma sorularına verilen cevapların sistematik olarak bazı kategoriler altında incelenmesi gereklidir. İlaveten araştırmacının yorumları da veri analizlerinde kullanılır. Çalışmada raporlanan verilerin analizinde içerik analizi tercih edilmiştir. İçerik analizinde Strauss ve Corbin (1990)'in önerdiği model kapsamında kodlama, kategorileri belirleme, kategorileri isimlendirme ve bu kategorilerin özelliklerinin tanımlanması gerçekleştirilmiştir. Araştırmacı tarafından ön okuması yapılan verilerin kod şemaları oluşturularak incelenmiş ve kodlama işlemi tamamlanmıştır. Böylece betimsel analizde özetlenen ve yorumlanan veriler içerik analizinde daha derin bir işleme tabi tutulmuş ve betimsel yaklaşımla fark edilemeyen kavram ve temalar bu analizle açığa çıkarılmıştır (Yıldırım ve Şimşek, 2018: 242).

\section{Bulgular ve tartışma}

Katılımcılardan elde edilen verilerin içerik analizine tabi tutulması sonucunda ortaya çıkan bulgular tablolar halinde aşağıda verilmiş ve yorumlanmıştır. Tablolarda yer alan sıklıklar farklı kültürel kimliğe (6 grup) ait kadınların toplam sayısı (4 kişi) üzerinden belirlenmiştir.

Tablo 2'de kültürel kimlikler ve mısır unu kullanımıyla özdeş yemeklere yönelik sorunun bulguları verilmiştir. Tabloda görüldüğü üzere ' kültürel kimlikler ve mısır unu kullanımıyla özdeş yemekler" teması ile "özdeş yemekler" kodu oluşturulmuştur. 
Tablo 2: Kültürel Kimlikler ve Mısır Unu Kullanımıyla Özdeş Yemekler

\begin{tabular}{|c|c|c|c|c|}
\hline Tema & $\begin{array}{c}\text { Kültürel } \\
\text { Kimlik }\end{array}$ & Doğrudan Alıntılardan Örnekler & $\begin{array}{c}\text { Kod } \\
\text { (Özdeş Yemek) }\end{array}$ & Sıklık \\
\hline \multirow{6}{*}{$\begin{array}{l}\text { Kültürel } \\
\text { Kimlikler ve } \\
\text { Misır Unu } \\
\text { Kullanımıyla } \\
\text { Özdeş } \\
\text { Yemekler }\end{array}$} & Manav & $\begin{array}{l}\text { K1: Yemeğimiz 'Malay". Ancak } \\
\text { gençler merak etmiyor...ögretmeye } \\
\text { çalış1yoruz...Unutulacak... } \\
\text { K3: Malay'a 'Buğday Mala" da } \\
\text { deriz. }\end{array}$ & $\begin{array}{l}\text { *Malay } \\
\text { (Buğday Mala) }\end{array}$ & 4 \\
\hline & $\mathrm{Laz}$ & $\begin{array}{l}\text { K17: Misır unundan Mihlama ya da } \\
\text { Kuymak yapılır... } \\
\text { K19: Laz kimliği Misır ekmeğiyle } \\
\text { anılır... }\end{array}$ & $\begin{array}{l}\text { *Mihlama *Kuymak } \\
* \text { Misır Ekmeği }\end{array}$ & $\begin{array}{l}4 \\
4 \\
3\end{array}$ \\
\hline & Muhacir & $\begin{array}{l}\text { K7: Muhacir denilince 'Kaçamak"... } \\
\text { K6: Bi de 'Loznik".. Herkes bilmez... }\end{array}$ & $\begin{array}{l}\text { *Kaçamak } \\
\text { *Asma Pidesi } \\
\text { (Loznik) }\end{array}$ & $\begin{array}{l}4 \\
2\end{array}$ \\
\hline & Abhaz & $\begin{array}{l}\text { K15: Çerkez tavuğu yanlış biliniyor } \\
\text { aslında 'Abhaz Cevizli Tavuğu... } \\
\text { K: 13: Abısta var bi de... }\end{array}$ & $\begin{array}{l}\text { *Cevizli Tavuk } \\
{ }^{*} \text { Abista } \\
\text { (Abhaz Pastas1) }\end{array}$ & $\begin{array}{l}4 \\
4\end{array}$ \\
\hline & $\begin{array}{r}\text { Çerkez } \\
\text { (Adige) }\end{array}$ & $\begin{array}{l}\text { K 24: Biz Şıpsi Paste yaparız... } \\
\text { Çerkez Tavuğu olan aslında Şıpsi } \\
\text { Paste... Yanlı̧ biliniyor. } \\
\text { K 21: Mamursa yaparı... }\end{array}$ & $\begin{array}{l}\text { *Şıpsi Paste } \\
\text { *Maramısa-Mamursa }\end{array}$ & $\begin{array}{l}4 \\
3\end{array}$ \\
\hline & Gürcü & $\begin{array}{l}\text { K 11: Biz misır ekmeğine "Cadi" deriz. } \\
\text { K 10: Lobyo Prhali yemeği var... }\end{array}$ & $\begin{array}{l}* \text { Cadi } \\
*(\text { Lobyo P1hali) }\end{array}$ & $\begin{array}{l}4 \\
2\end{array}$ \\
\hline
\end{tabular}

Manav kadınlar kendilerine yerli Türkmen ya da Yörük denildiğini ifade etmişlerdir. Kimlikleriyle özdeş yemek olarak bir kod üretmişlerdir. Bu kod malay yemeğidir. Malay, kadınların tamamı (4) tarafından özdeş yemek olarak onay görmüştür.

Laz kadınlar Karadeniz'den geldiklerini belirtmişlerdir. Kimlikleriyle özdeş yemek olarak üç kod üretmişlerdir. Bunlar mıhlama, kuymak ve mısır ekmeğidir. Özellikle mıhlamanın Laz kimliğiyle daha özdeş olduğu ifade edilmiştir. Bu kapsamda kadınların tamamı (4) mıhlama ve kuymak yemeğini, üç kadın ise mısır ekmeğini kimlikle özdeş olarak nitelemiştir.

Muhacir kadınlar Bulgaristan Türkü oldukları için kendilerine Muhacir denildiğini belirtmişlerdir. Kimlikleriyle özdeş yemek olarak iki kod üretmişlerdir. Bunlar kaçamak ve loznik (asma yapră̆ı pidesi) yemeğidir. Kaçamak kadınların tamamı (4) tarafından, loznik ise iki kadın tarafından özdeş yemek olarak onaylanmıştır. Loznik yemeğinin unutulmaya yüz tuttuğu ve daha az bilindiği anlaşılmıştır.

Abhaz kadınlar, kendilerine Apsua denildiğini ve Kuzey Batı Kafkasya’nın Karadeniz k1yılarından geldiklerini ifade etmişlerdir. Apsua; Abhaz kelimesinin orijinal ismi olup zamanla Abhaz ve halk arasında Abaza kelimesine dönüşmüştür (Argun vd., 2014: 14). Kadınlar kimlikleriyle özdeş yemek olarak iki kod üretmişlerdir. Bunlar Abhaz cevizli tavuk ve abıstadır. Kadınların tamamı (4) mısır unuyla yapılan ve Çerkez tavuğu olarak bilinen yemeğin aslında Abhaz cevizli tavuk olduğunu ifade etmişlerdir. Cevizli tavuk ve abıstayı kadınların tamamı (4) kimlikleriyle özdeş yemek olarak tasdik etmişlerdir. 
Çerkez (Adige) kadınlar Rusya'dan sürgünle geldiklerini dile getirmişlerdir. Kimlikleriyle özdeş yemek olarak iki kod üretmişlerdir. Bunlar şipsi paste ve maramısadır. Tüm kadınlar (4), Çerkez tavuğu olarak bilinen yemeğin aslında kimlikleriyle özdeş olan şipsi paste olduğunu belirtmişlerdir. Bu kapsamda Çerkez (Adige) kadınlar, Abhaz kökenli kadınların Abhaz cevizli tavuk ile ilgili söylemlerini de teyit etmişlerdir. Bu bulgu, yemeklerin kültür yanılsamasına yol açtığını hatta kültür çatışması doğurabileceğini düşündürmüştür. Standage’ye göre (2016) yemek, çağlar boyunca fizyolojik ihtiyacın ötesinde toplumsal değişim ve örgütlenmede, coğrafi rekabette, endüstriyel ve ekonomik güçte ve askeri çatışmalarda önemli bir unsurdur (Öztek, 2019: 2). Hatta ulusal kimlik düzeyinde; Yunanistan ve Türkiye arasında paylaşılamayan ve tartışma konusu olan birçok yemek olduğu bilinmektedir (Fırat, 2014: 135). Bu tespitler çalışma bulgularıyla paralel olup yemeklerin kültür çatışmasına yol açabileceğini göstermesi bakımından önemlidir. İlaveten kültürel kimliğimizin bir parçası olan ideolojilerin, aslında göstergesel araçlar olan yemek kültürü üzerinden şekillendiği de refere edilmiştir.

Gürcü kadınlar, Acara Gürcüleri olduklarını ifade etmişlerdir. Acara Gürcülerinin en önemli özelliği Osmanlı İmparatorluğu zamanında İslam’a geçmiş olmaları ve Gürcülerin, Gürcü kültüründen çok Türk kültürü ile özdeş hale gelmesi ya da akrabalık bağı oluşturmasıdır (Zeyrek, 2001: 94). Gürcü kadınlar kimlikleriyle özdeş yemek olarak iki kod üretmişlerdir. Bunlar; cadi (mısır unu ekmeği) ve lobyo pıhali yemeğidir. Cadi, kadınların tamamı (4) tarafından, lobyo pıhali ise iki kadın tarafından kimlikle özdeş yemek olarak onaylanmıştır. Lobyo pıhalinin daha az bilindiği hatta unutulmaya yüz tuttuğu anlaşılmıştır.

Tablo 3'te farklı kültürel kimliklerde mısır unuyla yapılan yemeklerin hazırlanmasına yönelik sorunun bulgularına yer verilmiştir.

Tablo 3: Mısır Unu Kullanımının Kültürel Kimliklerde Uygulama Fark1

\begin{tabular}{|c|c|c|c|c|c|}
\hline Tema & $\begin{array}{c}\text { Kültürel } \\
\text { Kimlik }\end{array}$ & $\begin{array}{l}\text { Özdeş } \\
\text { Yemek }\end{array}$ & Doğrudan Alıntılar & \begin{tabular}{l}
\multicolumn{1}{c}{ Kod } \\
(Kullanım \\
Farkı)
\end{tabular} & Sıklık \\
\hline \multirow[b]{3}{*}{$\begin{array}{l}\text { Mısır Unu } \\
\text { Kullanımının } \\
\text { Külttürel } \\
\text { Kimliklerde } \\
\text { Ayırt Edici } \\
\text { Özellikleri }\end{array}$} & Manav & Malay & K 4: Üzerine dartı konur... & $*$ Dart1 & 4 \\
\hline & Laz & $\begin{array}{l}\text { Mihlama- } \\
\text { Kuymak } \\
\text { Misır ek. }\end{array}$ & $\begin{array}{l}\text { K 18: Mihlamada peynir ve } \\
\text { tereyağ çoktur... } \\
\text { K 19: Kuymak da, misır unu } \\
\text { çok... Bir de misır ekmeğimiz } \\
\text { var... }\end{array}$ & $\begin{array}{l}\text { *Peynir fazla } \\
\text { *Tereyağ } \\
\text { fazla } \\
\text { *Misır unu } \\
\text { fazla }\end{array}$ & $\begin{array}{l}4 \\
4 \\
4 \\
-\end{array}$ \\
\hline & Muhacir & $\begin{array}{l}\text { Kaçamak } \\
\text { Loznik }\end{array}$ & $\begin{array}{l}\text { K8: Kaçamak tenceremiz } \\
\text { ve oklavamız var. Bugün } \\
\text { bulamayız... } \\
\text { K 7: Tatllsına pekmez tuzlusuna } \\
\text { patates koyarız... } \\
\text { K 5: Taze asma yaprağl altına ve } \\
\text { üstüne koyarı.. }\end{array}$ & $\begin{array}{l}\text { *Oklava } \\
\text { *Tencere } \\
\text { *Pekmez } \\
\text { (tatlı) } \\
\text { *Haşlanmış } \\
\text { patates } \\
\text { (tuzlu) } \\
\text { *Kaymak } \\
\text { *Taze asma } \\
\text { yaprağ1 }\end{array}$ & $\begin{array}{l}4 \\
4 \\
4 \\
4 \\
4 \\
2\end{array}$ \\
\hline
\end{tabular}




\begin{tabular}{|c|c|c|c|c|}
\hline Abhaz & $\begin{array}{l}\text { Cevizli } \\
\text { Tavuk } \\
\text { Abista }\end{array}$ & $\begin{array}{l}\text { K 14: İçine Pırpılıcıka denilen } \\
\text { Abhaz acıkası konulur. Havanı } \\
\text { da özel... } \\
\text { K 13: Ceviz fazladır...Ayrıca } \\
\text { abıstada Abhaz peyniri var. }\end{array}$ & $\begin{array}{l}\text { *Pırpılicika } \\
\text { *Ağaç havan } \\
\text { *Ceviz daha } \\
\text { fazla. } \\
\text { *Abhaz } \\
\text { peyniri }\end{array}$ & $\begin{array}{l}4 \\
4 \\
4 \\
4\end{array}$ \\
\hline $\begin{array}{l}\text { Çerkez } \\
\text { (Adige) }\end{array}$ & $\begin{array}{l}\text { Şıpsi } \\
\text { Paste } \\
\text { Mamursa }\end{array}$ & $\begin{array}{l}\text { K 22: Şipsi Paste 'de ceviz olmaz, } \\
\text { mısır unu vardır... } \\
\text { K 23: Mamursayı çerkez } \\
\text { peyniriyle yeriz, Şipsi koyarız, } \\
\text { tereyağı da fazladır... }\end{array}$ & $\begin{array}{l}\text { *Ceviz yok. } \\
\text { *Misır unu } \\
\text { fazla } \\
\text { *Çerkez } \\
\text { peyniri } \\
\text { *Şipsi } \\
\text { *Tereyağ1 } \\
\text { fazla }\end{array}$ & $\begin{array}{l}4 \\
4 \\
4 \\
4 \\
4\end{array}$ \\
\hline Gürcü & $\begin{array}{l}\text { Cadi } \\
\text { Lobia }\end{array}$ & $\begin{array}{l}\text { K 10: 'Pileki”' de pişer... } \\
\text { K 11: Karalahana ve barbunya } \\
\text { en temel farktır... }\end{array}$ & $\begin{array}{l}\text { *Pileki } \\
\text { *Karalahana } \\
\text { ve Barbunya }\end{array}$ & $\begin{array}{l}4 \\
3\end{array}$ \\
\hline
\end{tabular}

Tablo 3 'te görüldüğü üzere '"mısır unu kullanımının kültürel kimliklerde ayırt edici özellikleri” teması ile "kullanım farkı" kodu oluşturulmuştur. Özellikle kullanım farkı kodunu daha net ortaya koymak için mısır unuyla yapılan yemeklerin tariflerine ve görsellerine yer verilmiştir.

Manav kadınların tamamı malay yemeğinin yapılışıyla ilgili genel olarak şu tarifi vermişlerdir. Kaynayan suya mısır unu atılır ve sürekli karıştırılır. Hamur kıvamına gelen lapa tahta kaşığa yapışmadığında piştiği anlaşılır. Bu karışım kaşıkla tepsiye dizilir. Üzerine dartı dökülür. Kadınların tamamı (4) kullanım farkına yönelik bir kod üretmişlerdir. Bu kod dartıdır. Dartı, Manav kimliğiyle özdeş süt kaymağının kaynatılmasıyla yapılan bir sostur. (Alyakut ve Üzümcü, 2018: 1858). Bu sos, kadınların tamamı tarafından ayırt edici özellik olarak onaylanmıştır. Resim 1'de malay ile dartının görseli verilmiştir.
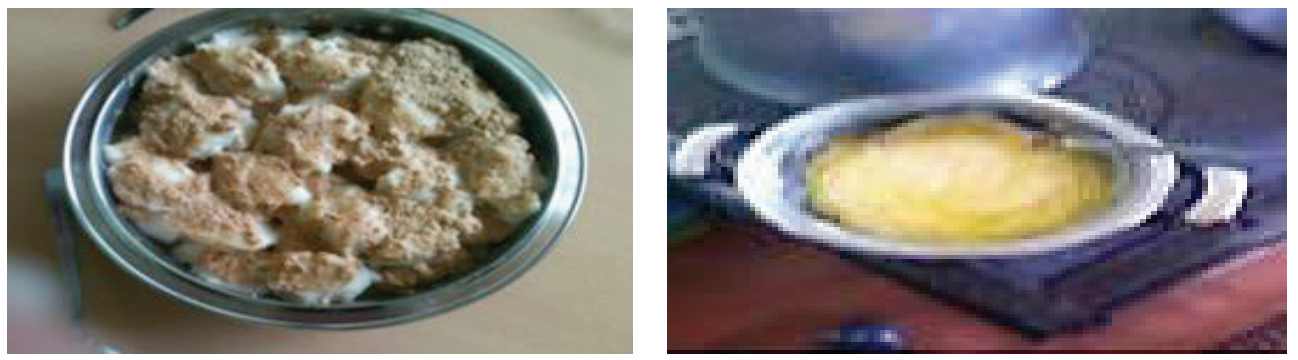

Resim 1: Malay ve Dartı (Alyakut ve Üzümcü, 2018).

Laz kültüründe mıhlama ya da kuymak temel yiyecektir. Bu yiyeceğe Trabzon ve çevresinden göç edenler kuymak, Rize ve çevresi mıllama demektedir. Kuymak yapılırken mısır unu fazla konulur mıhlama yapılırken peynir ve tereyağı fazladır (Süfer ve Sezer Çelebi, 2014: 461). Kadınların verdiği mıhlama tarifi şöyledir. Mısır unu tereyağında kavrulur. İçine tel peynir katılır ve tahta kaşıkla karıştırılarak pişirilir. Kadınların tamamı (4) bu yemeğin 
ayırt edici özelliğine yönelik üç kod üretmişlerdir. Bunlar; tereyağı, peynir ve kullanılan mısır unu miktarıdır. Resim 2'de mıhlama görseli verilmiştir. Lazlarda mısır ekmeği ise buğday ekmeği kadar kıymetli olup mısır ekmeği için ayırt edici kod belirtilmemiştir.

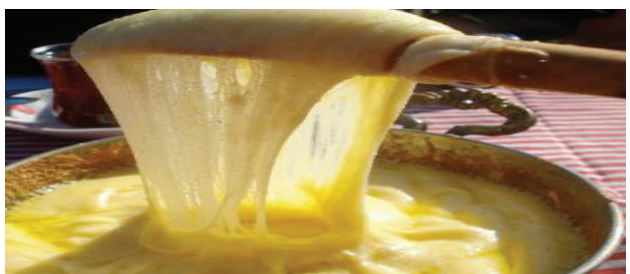

Resim 2: Mihlama (https://yemek.com/, 2019).

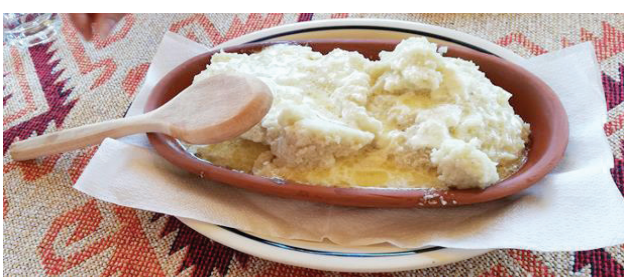

Resim 3: Kaçamak (Alyakut, 2019).

Muhacir kadınlar kaçamak yapılışının, malay gibi olduğunu ifade etmişlerdir. Ayırt edici özellik olarak beş kod üretmişlerdir. Bu kodlar karıştırmak için kullanılan kaçamak oklavası, kaçamak tenceresi ve yemeğe konulan üç çeşit sostur. Kaçamak, içine katılan soslarla tatlı ya da tuzlu yapılabilir. Tatlı olana pekmez koyulurken tuzlu olana kaymak veya haşlanmış patates sos olarak konulur. Kaçamak oklavası ve tenceresi de geleneksel mutfak araçları arasındadır. Ayırt edici bu kodlar tüm kadınlar (4) tarafından onaylanmıştır. Resim 3’te Kaçamak görseli verilmiştir.

Muhacirlerin diğer lezzeti lozniktir. Loznik, Bulgaristan Muhacirlerinin özellikle Pomakların Kocaeli kent gastronomisine yaptığı önemli katkılardan biridir. Kartepe ilçesinin Karatepe köyünde halen yaygın olarak yapılmaktadır. Kadınların verdiği loznik tarifi şöyledir. Mısır unu, yoğurt, sıvı yağ, taze soğan, nane, tuz, çok az şeker ve istenilen baharatlar karıştırılarak boza kıvamında bir hamur yapılır. Tepsiye yayılan taze asma yapraklarının üzerine hazırlanan bu harç dökülür ve üstüne tekrar taze asma yaprakları konulur. Taş firında pişirilir. Bu yemeği bilen iki kadın ayırt edici özellik olarak bir kod üretmiştir. Bu kod taze asma yaprağı kullanılmasıdır. Loznik yapım aşamaları ve görseli Resim 4’te verilmişstir.
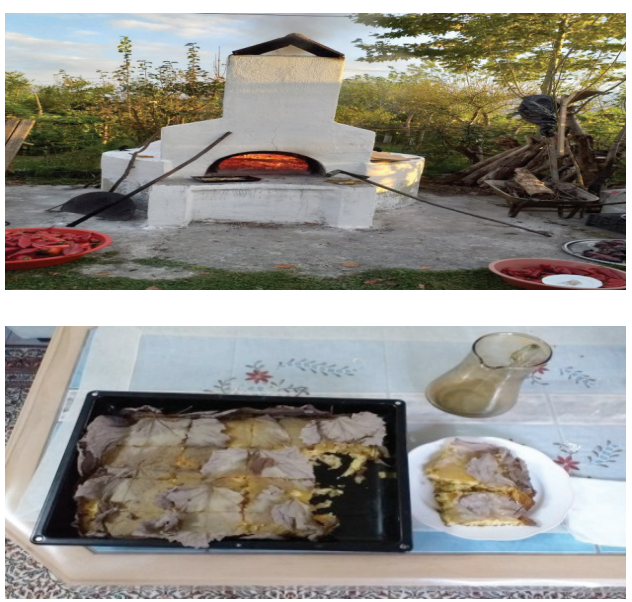
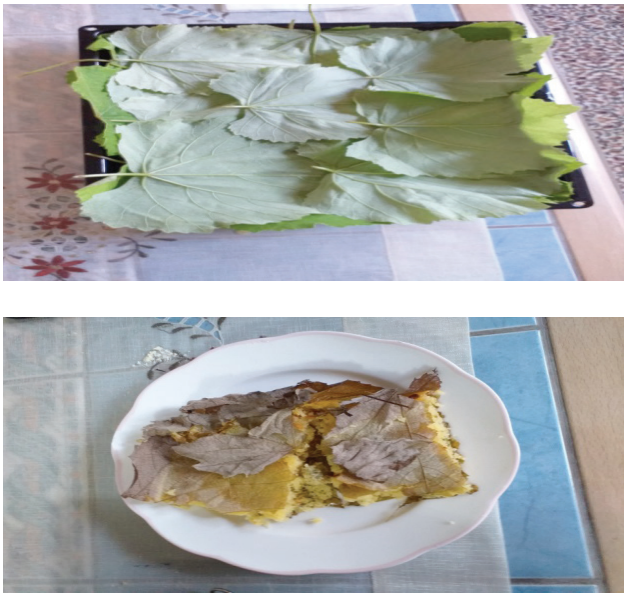

Resim 4: Loznik (Ŭgurkan, 2019). 
Abhaz kadınların verdiği tariflerle Abhaz cevizli tavuk şöyle yapılır. Yemeğin sosu için ceviz, yağı çıkana kadar geleneksel Abhaz havanında (ağaç havan) dövülür ve çıkan ceviz yağı sos olarak kullanılmak üzere ayrılır. Bir kabın içine dövülen ceviz, abısta, pırpılıcıka denilen Abhaz acıkası, dövülmüş sarımsak, kişniş, reyhan otu ve azar azar tavuk suyu koyularak karıştırılır. Boza kıvamına getirilir. Karışıma haşlanmış tavuk didiklenerek konulur ve ayrılan ceviz yağının bir kısmı içine bir kısmı da üzerine ilave edilir. Bu yemekte ceviz yoğunluğu ve pırpılıcıka önemlidir. Bu kapsamda kadınların tümü (4) ayırt edici özellik olarak üç kod üretmişlerdir. Bunlar ceviz miktarı (fazla), ağaç havan ve pırpılıcıkadır. Resim 5 'te Abhaz cevizli tavuk yapım aşamaları ve görseli verilmiştir.
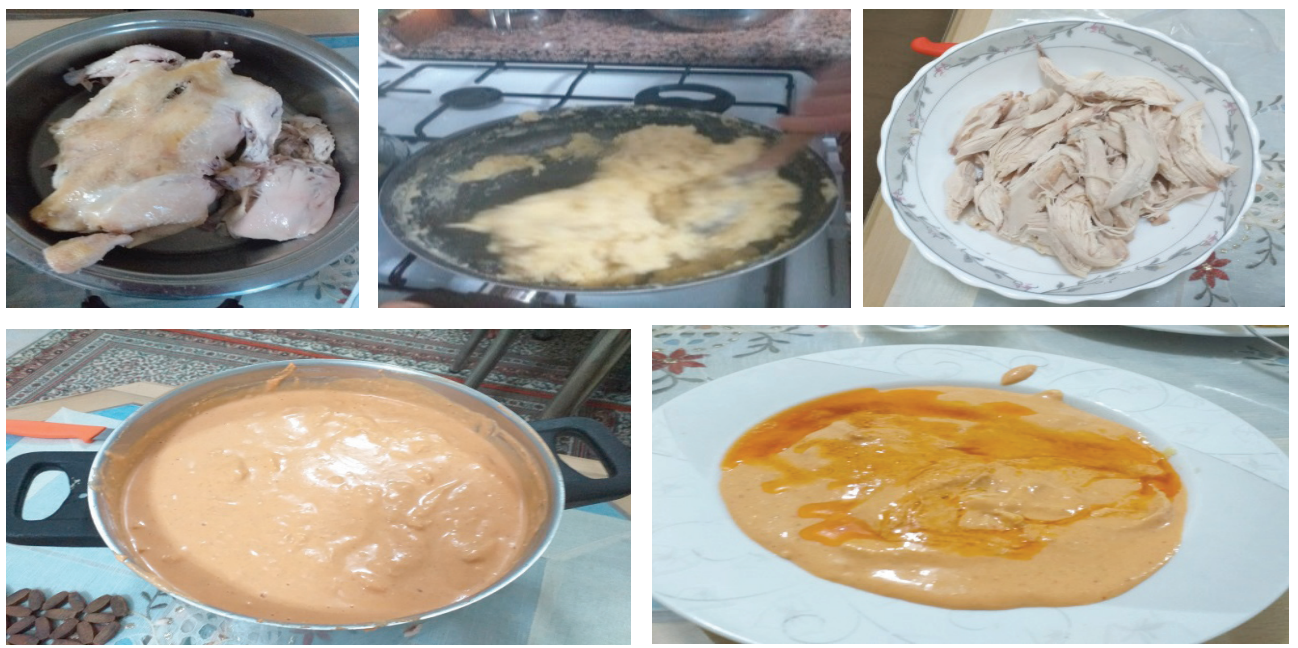

Resim 5: Abhaz Cevizli Tavuk (Uğurkan, 2019).

Abhaz kimliğiyle özdeş diğer lezzet olan abısta tarifi ise şöyledir. Kaynayan suya mısır unu atılır. Tahta kaşıkla suyunu çekene kadar karıştırılır. Kıvama gelen pastanın aralarına Abhaz peyniri koyulur ve servis edilir. Kadınların tamamı ayırt edici özellik olarak bir kod üretmişlerdir. Bu kod üzerine konulan Abhaz peyniridir. Resim 6'da abısta yapım aşamaları ve görseli verilmiştir.
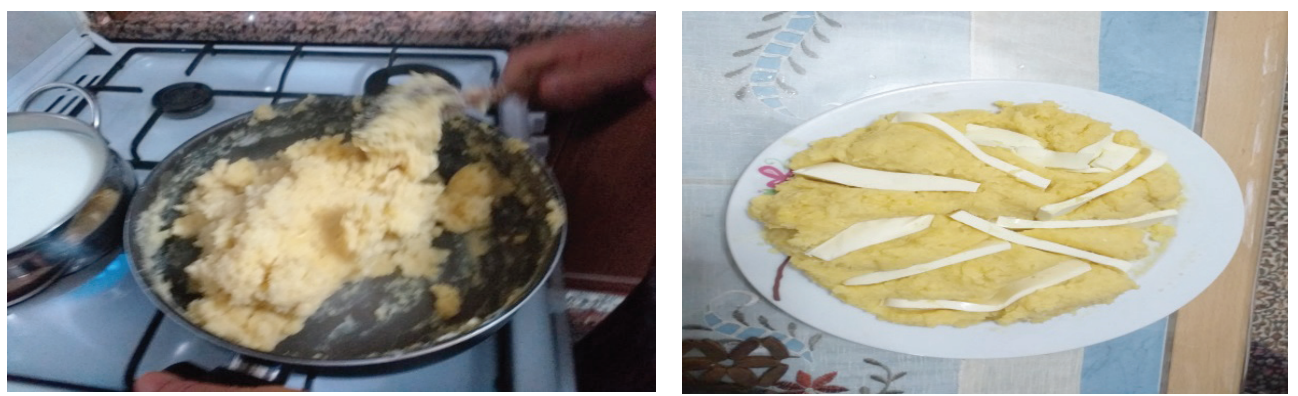

Resim 6: Abısta- (Ŭgurkan, 2019). 
Çerkez (Adige) kadınlar tarafından verilen şipsi pastenin tarifi şöyledir. Şipsi paste için; geleneksel Adige salçasıyla kuru soğan yağda kavrulur. Üzerine mısır unu lapası, pul biber ve sarımsak eklenir. Kavrulan bu karışıma tavuk suyu dökülerek boza kıvamına getirilir. Tepsinin ortasına hazırlanan bu geleneksel sostan konulur. Haşlanan tavuklar içine veya etrafına diziler. Kadınlar ayırt edici özellik olarak iki kod üretmişlerdir. Bunlar ceviz (yok) ve mısır unu (fazla) miktarıdır. Şipsi pastede ceviz yoktur, mısır unu fazladır. Resim 7'de şipsi pastenin görseli verilmiştir.



Resim 7: Şipsi Paste (https://ibikibik.tumblr.com/, 2019).

Çerkez (Adige) kadınlar tarafından diğer lezzet olan mamursa tarifi şöyledir. Mamursa, abısta gibi pişirilir ancak pasta piştikten sonra ortası açılır ve ortasına tereyağı, Çerkez peyniri veya şipsi koyulur. Bu kapsamda kadınların tümü (4) ayırt edici özellik olarak bu üç kodu üretmişlerdir.

Gürcü kadınlardan elde edilen bilgilerle cadi ve lobya pıhali tarifi şöyle genellenebilir. Mısır unu, maya, tuz ve su yoğrularak yumuşak bir hamur yapılır. Mayalanmaya bırakılır. Kabaran hamur pileki denilen taş kalıplarda köz ateşinde pişirilir. Kadınların tamamı (4) ayırt edici özellik olarak bir kod üretmişlerdir. Bu kod pilekidir. Resim 8'de pileki içinde cadi ve lobya pıhali görseli verilmiştir.
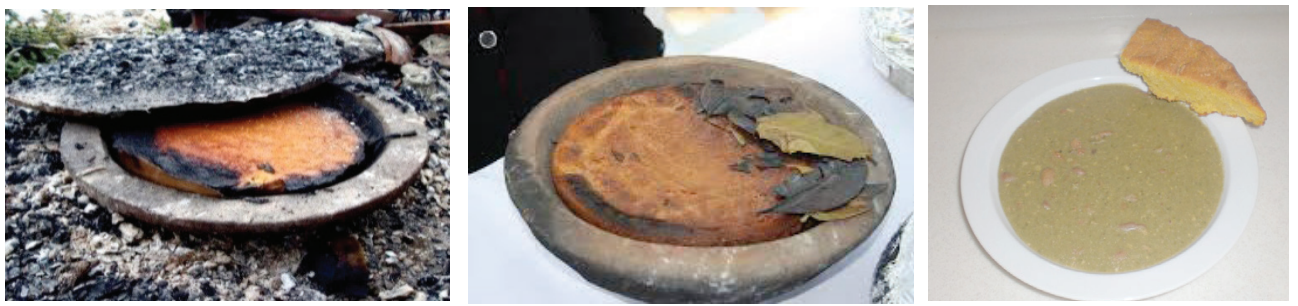

Resim 8: Pileki içinde Cadi ve Lobya Pıhali (http://kutluata.net/; (www.flickr.com, 2019).

Diğer Gürcü yemeği lobia pıhalinin ise tarifi şöyledir. Önceden 1slatılmış barbunya kıyılmış kara lahanalarla kaynatılır. Bu karışıma mısır unu katılır, üzerine tereyağı dökülür. Üç kadın tarafından barbunya ve kara lahana ayırt edici özellik olarak kodlanmıştır. 
Gellner'e (2007: 59) göre gastronomik, ritüel ve doktriner farklılıklar bireylerin kimliklerini belirtmesinde etkilidir. Çünkü insanlar kimliklerini sosyal durumlarının bu özgüllüğü ile ifade etmektedir. Özellikle yemek hazırlamada kullanılan besinler ve kültürel grubun sınırları gibi unsurlar, birey statüsünü göstermesi bakımından önemlidir (Sönmez Selçuk, 2012: 124). Yemek pişirmede kullanılan araçlar ise sosyal ve kültürel mesajların aktarılmasını sağlamaktadır (Goode, 2005:172). Bu bilgileri destekleyen çalışma bulguları yemeklerin kimlikler üzerinde belirleyici olduğunu ortaya koymuştur.

Kültürel kimliklere ait yemeklerin grup aidiyetine ve yörenin yemek kültürüne katkısına yönelik sorunun bulguları Tablo 4'te verilmiş̧tir. Tabloda görüldüğü üzere ' kültürel kimliklere ait yemeklerin grup aidiyetine ve yörenin yemek kültürüne katkısı" teması ile "grup aidiyeti ve yemek kültürüne katkı" kodu oluşturulmuştur.

Manav kadınların tamamı (4) yemeklerin sosyalleşme/dayanışma aracı ve kimlik göstergesi olduğuna yönelik iki kod üretmişlerdir.

Laz kadınların tümü (4) yemeklerin birlik ve beraberlik aracı olduğuna ve turizme katk1 sağlayarak bölgenin mutfak kültürüne zenginlik kattığına yönelik üç kod üretmişlerdir. Kadınlardan ikisi ise kimliklerin dinamik kalmasında ve grup aidiyetinin korunmasında yemeklerin etkili olduğuna yönelik iki kod üretmiş̧ir.

Muhacir kadınların tamamı (4) yemekleriyle bölgede turizm açısından görünür olmadıklarına bu nedenle mutfak kültürüne ve turizme katkı sağlayamadıklarına ancak yemekleri sayesinde kim olduklarını hatılladıklarına ve bir arada olduklarına yönelik dört kod üretmiş̧lerdir.

Abhaz kadınların tamamı (4) yemeklerin birleştirici bir araç olduğuna ve grup aidiyetini artırdığına yönelik iki kod üretirken üç kadın ise yemeklerin sembolik bir gösterge olduğuna ve yörenin mutfak kültürüne katkı sağladığına yönelik iki kod üretmişlerdir.

Çerkez (Adige) kadınların tümü (4) yemeklerin sembolik bir gösterge olarak kimliklerine işaret ettiğgine, yardımlaşma aracı olarak görev yaptığına ve yöre mutfağına katkı sağladığına yönelik dört kod üretmişlerdir.

Gürcü kadınların tümü (4) yemeklerin grup aidiyetini pekiş̧irdiğine ve onları bir araya getirerek sosyalleştirdiğine yönelik iki kod üretirken, üç kadın ise yemekleriyle öne çıkamadıklarından kimliklerinin de görünür olamadığına yönelik bir kod üretmiştir. 
Tablo 4: Kültürel Kimliklere Ait Yemeklerin Grup Aidiyetine ve Yörenin Yemek Kültürüne Katkısı

\begin{tabular}{|c|c|c|c|c|c|}
\hline Tema & $\begin{array}{c}\text { Kültürel } \\
\text { Kimlik }\end{array}$ & $\begin{array}{l}\text { Özdeş } \\
\text { Yemek }\end{array}$ & Doğrudan Alıntılar & $\begin{array}{l}\text { Kod } \\
\text { (Grup Aidiyeti } \\
\text { ve } \\
\text { Yemek } \\
\text { Külttürüne } \\
\text { Katkı) }\end{array}$ & Sıklık \\
\hline \multirow{6}{*}{$\begin{array}{l}\text { Kültürel } \\
\text { Kimliklere } \\
\text { Ait } \\
\text { Yemeklerin } \\
\text { Grup } \\
\text { Aidiyetine } \\
\text { ve } \\
\text { Yörenin } \\
\text { Yemek } \\
\text { Kültürüne } \\
\text { Katkısı }\end{array}$} & Manav & Malay & K 2: Malay düğünlerde yapılır... & $\begin{array}{l}\text { *Dayanışma/ } \\
\text { Sosyalleşme } \\
\text { *Kimlik } \\
\text { göstergesi }\end{array}$ & $\begin{array}{l}4 \\
4\end{array}$ \\
\hline & Laz & $\begin{array}{l}\text { Mihlama } \\
\text { Kuymak } \\
\text { Misır } \\
\text { Ekmeği }\end{array}$ & $\begin{array}{l}\text { K 20: Kahvaltı da yapar, beraber } \\
\text { yeriz. .. } \\
\text { K 19: İşletme açan kadınlar var. } \\
\text { Mihlama, Kuymak kahvaltılarda } \\
\text { isteniyor... Misır ekmeği ise her } \\
\text { zaman var... Turizme açıldık... } \\
\text { Biz her yerdeyiz... }\end{array}$ & $\begin{array}{l}\text { *Birlik- } \\
\text { beraberlik } \\
\text { *Kimlik } \\
\text { göstergesi } \\
\text { * Grup Aidiyeti } \\
\text { *Turizme katk1 } \\
\text { *Mutfak } \\
\text { kültürüne katk1 }\end{array}$ & $\begin{array}{l}4 \\
3 \\
3 \\
4 \\
4\end{array}$ \\
\hline & Muhacir & $\begin{array}{l}\text { Kaçamak } \\
\text { Loznik }\end{array}$ & $\begin{array}{l}\text { K 7: Kartepe, turizm bölgesi... } \\
\text { Yabancı geliyor. Özellikle yöresel } \\
\text { yemekler yapllyor ancak bizim } \\
\text { yemekler yok... } \\
\text { K 8: Bizi bir araya toplar, kim } \\
\text { olduğumuzu hatırlatır... }\end{array}$ & $\begin{array}{l}\text { *Turizme- } \\
\text { mutfak } \\
\text { kültürüne katk1 } \\
\text { az } \\
\text { *Kimlik } \\
\text { görünür değil } \\
\text { *Kimlik } \\
\text { göstergesi } \\
\text { *Birlik- } \\
\text { Beraberlik }\end{array}$ & $\begin{array}{l}4 \\
4 \\
4 \\
4\end{array}$ \\
\hline & Abhaz & $\begin{array}{l}\text { Cevizli } \\
\text { Tavuk }\end{array}$ & $\begin{array}{l}\text { K 15: Herkes Cevizli Tavuk'un } \\
\text { bize ait olduğun bilir. Birbirimizi } \\
\text { davet eder, hep birlikte yeriz... } \\
\text { Bütün özel günlerde pişiririz... }\end{array}$ & $\begin{array}{l}\text { *Birleştirme } \\
\text { aracı } \\
\text { *Sembolik } \\
\text { değer } \\
\text { *Grup aidiyeti } \\
\text { *Mutfak } \\
\text { kültürüne katk1 }\end{array}$ & $\begin{array}{l}4 \\
3 \\
4 \\
3\end{array}$ \\
\hline & $\begin{array}{l}\text { Çerkez } \\
\text { (Adige) }\end{array}$ & $\begin{array}{l}\text { Şıpsi/ } \\
\text { Paste } \\
\text { Mamursa }\end{array}$ & $\begin{array}{l}\text { K 21: Anneme misır unu hediye } \\
\text { getirirdik, çok sevinirdi, çünkü } \\
\text { misır unu demek, Şipsi Paste, } \\
\text { Mamursa demekti... }\end{array}$ & $\begin{array}{l}\text { *Kimlik } \\
\text { göstergesi } \\
\text { *Sembol } \\
\text { *Yardımlaşma } \\
\text { *Mutfak } \\
\text { kültürüne katkı }\end{array}$ & $\begin{array}{l}4 \\
4 \\
4 \\
4\end{array}$ \\
\hline & Gürcü & $\begin{array}{l}\text { Cadi } \\
\text { Lobia }\end{array}$ & $\begin{array}{l}\text { K 15: Gürcüler, burada çok ama } \\
\text { yemeklerimiz pek bilinmiyor. Ama } \\
\text { biz yemeklerimizi hep yaparı... }\end{array}$ & $\begin{array}{l}\text { *Kimlikler } \\
\text { görünür değil } \\
\text { *Grup Aidiyeti } \\
\text { *Sosyalleşme } \\
\text { aracı }\end{array}$ & $\begin{array}{l}3 \\
4 \\
4\end{array}$ \\
\hline
\end{tabular}


Goode'ye (2005: 174) göre yemek, etnik gruplar için belirleyicidir ve aynı gruba ait bireylerin aynı yemekleri yemesiyle pozitif kimlik yaratılmakta ve dayanışma artmaktadır. İlaveten yemek tüm unsurları ile toplumsal güç göstergesi olmasının yanı sıra toplum içindeki sosyalleşme, grup aidiyeti ya da çatışmalarda simgesel bir rol üstlenmektedir (Öztek, 2019: 18). Kimliği olumlu/olumsuz yönleri ile tanımlanmaya çalışan yemeğin, dostluk, kardeşlik ve dayanışma gibi homojenleştirici bir kimlik oluşumuna pozitif katkı sağlamasının yanında ayrımlar, sınırlar ve düşmanlıklar üzerinden diyalektik bir standartlaştırma süreci ve negatif bir katkıyı da içerisinde barındırdığı belirtilmektedir (Yıldırım, 2019: 193). Bu kapsamda çalışma bulguları; kimliklerle özdeş yemeklerin dayanışma yarattığını, birlik ve beraberlik oluşturduğunu, yaşam geçiş dönemlerinde ve/veya günün tüm öğünlerinde bu yemeklerin yapılarak sosyalleşmeye katkı sağladığını ortaya koymuştur. Ayrıca yöredeki kültürel farklılıkların zenginlik yaratarak yöre gastronomisine ve turizmine katkı sağladığı da desteklenmiştir (Duran, 2011, Bucak ve Aracı, 2013, Göğebakan, 2015).

\section{Sonuç}

Kocaeli ili Kartepe ilçesinde yapılan bu çalışmada kültürel kimliklerin mısır unuyla yapılan yemekleri nasıl şekillendirdiği ortaya koyulmaya çalışılmıştır. Bu kapsamda şu sonuçlara ulaşılmıştır.

Bu çalışma Kartepe ilçesinde yaşayan farklı kültürel kimlikleri ve kimliklerle özdeş mısır unuyla yapılan yemekleri ön plana çıkarmıştır. Bu kapsamda hem bölgenin çok kültürlülüğü hem de bu kültürel çeşitliliğe bağlı mısır unuyla yapılan yemeklerin fazlalığı dikkat çekmiştir. Yöre mutfağı çok kültürlülükten beslenmiş ve farklı kültürel kimliklerin yemek kültürü, Kartepe mutfağı özelinde Kocaeli mutfağının oluşmasına katkı sağlamıştır. İlaveten kimlikle özdeş olan yemeklerin aynı grup içinde birlik ve beraberlik duygusunu oluşturduğu ve kültürel kimlikleri dinamik tuttuğu saptanmıştır.

Kültürel kimliklere ait geleneksel mutfakların halen çok yönlü olarak sürdürüldüğü ve mısır unuyla yapılan birçok yemeğin var olduğu belirlenmiştir. Özellikle mısır ekmeği, kaçamak, mıllama gibi yemeklerin çok bilinmesine rağmen malay, loznik gibi yemeklerin unutulmaya yüz tuttuğu ortaya koyulmuştur. Abhaz yemeği olan Abhaz cevizli tavuğunun ise Çerkez tavuğu olarak yanlış kültüre addedildiği tespit edilmiştir. Bu kapsamda yemeklerin kimlik yanılsamasına neden olabildiği hatta kültür çatışması doğurabileceği sonucuna ulaş1lmıştır.

Çalışmada kültürel kimliğe ait yemeklerin coğrafya ve sosyal dokuyla bağlantılı olduğu ve bu unsurların yalnızca yemek pişirme tekniğine değil, kullanılan malzemelere ve ekipmanlara da yansıdığı tespit edilmiştir. Bu tespit Muhacirlerin kaçamak yaparken kaçamak tenceresi, kaçamak oklavası veya taze asma yaprağı kullanmaları ya da Gürcülerin cadi yaparken pileki denen pişirme kabı veya karalahana-barbunya gibi yörelerine ait besinleri kullanmalarıyla desteklenmiştir. Bu malzemelerin ve ekipmanların kimliğin doğrudan bir göstergesi olduğu sonucuna ulaşılmıştır.

Farklı kültürel kökene ait kadınların çoğunun kendi kültürlerini ve yemeklerini önemsedikleri ve yaşam evrelerinde veya günün öğünlerinde bu yemekleri yaparak sosyalleştikleri 
ve dayanışma sağladıkları saptanmıştır. Ayrıca kadınların her birinin kendi kültürüne ait damak tatlarını unutturmamak adına gençlere öğretmeye çalışmaları da kimlik yemek ilişkisini göstermesi bakımından önemli bir tespittir. Bu tespit yemeklerin kimliklerin şekillenmesinde etkili olduğu söylemine de katkı sağlamıştır.

Türkiye'nin önemli turizm bölgelerinden biri olan Kartepe ilçesi, kültürel kimliklerin turizm kapsamında görünürlüğü ve bilinirliği açısından değerlendirildiğinde, Laz kimliğinin yemekleriyle yörede baskın olduğu ve yöre restoranlarında yapılan yemekleri üzerinden kimliklerinin daha görünür ve bilinir olduğu tespit edilmiştir. Diğer kültürlere ait yemeklerin ise yöre restoranlarında yapılmadığından kimliklerinin de öne çıkamadığı saptanmıştır. Bu anlamda yemek kimlik ilişkisinin turizm kapsamında önemli bir çekicilik unsuru olarak değerlendirilmesinin önemli olduğu ortaya çıkmıştır. Böylece kültürel kimliklerin görünürlüğü arttığ1 gibi yörenin gastronomi potansiyeline de katkı sağlanmış olacaktır. Bu katkı turizm ekseninde yerel halkın kalkınmasına destek vererek ülke ekonomisine de katma değer sağlayacaktır.

Sonuç olarak kültürel kimliklerin mısır unuyla yapılan yemekleri çeşitlendirdiği ve bu çeşitliliğin kimlikler üzerinden yemekleri daha görünür ve bilinir kıldığı belirlenmiştir. Bu kapsamda Kartepe ilçesinde yaşayan Gürcü, Çerkez (Adige), Muhacir, Abhaz, Laz ve Manav kökenli halkların kültürel farklılıklarının mısır unu kullanımına yansıdığı ortaya koyulmuştur. Yemeklerin yapılışında benzerlikler olsa da belirgin farklılıklar olduğu bu farklılıkların kimlikler üzerinden şekillendiği sonucuna ulaşılmıştır.

Sonuçlar değerlendirildiğinde şu öneriler getirilebilir:

- Kartepe ilçesi, Kocaeli’nin en gözde turizm bölgelerinden biridir. Bölgenin farklı kültürel yapısı yemek çeşitliliğine de yansıdığından bu yemeklerin gastronomi turizmi kapsamında değerlendirilmesi önemlidir. Yöredeki mısır unundan yapılan farklı lezzetlerin restoran ve otellerde sunulması turistler için çekicilik unsuru olacaktır.

- Turizm kapsamında mıhlama ve kuymak yemekleriyle daha çok Laz kimliğinin öncelendiği yörede, kaçamak, malay gibi diğer kültürlere ait yemeklerin de restoran mönülerinde yer almasıyla bu kimlikler de görünür ve bilinir kılınacaktır.

- Kartepe ilçesinde yaşayan halklara, kimlik, kültür ve yemek ilişkisi bağlamında eğitimler/seminerler vb. verilmelidir. Bu eğitimlerle halklar, kimliklerinin özelliklerini taşıyan kültürel değerlerini önemseyecek ve farkındalıkları artacaktır.

- Farkındalığ́ artan halk kültürel kimliğine sahip çıkarak, somut olmayan kültürel miras (yemek vb.) değerlerini koruyacak, yaşatacak ve gelecek nesillere aktarmak için çaba sarf edecektir. 


\section{Kaynaklar}

Abdulrezzak, A. O. (2016). Sosyo-kültürel bağlamda yemek ve iletişim. 25-27 Mayıs, III. Uluslararası Türk Dünyası Araştırmaları Sempozyumu. Bakü.

Alyakut, Ö. ve Üzümcü Polat, T. (2018). Gastronomi turizmi bağlamında Kandıra beslenme kültürü ve unutulmaya yüz tutmuş lezzetleri Goncaaydın köyü örneği. Uluslararası Çoban Mustafa Paşa ve Kocaeli Tarihi-Kültürü Seтроzуити IV Bildirileri. (1. cilt) Kocaeli.

Argun, A., Agumaa, A, Sagaria, B., Acincal, B., vd. (2014). İlk çağlardan günümüze Abhazya tarihi. S. Lakoba ve diğerleri (Ed.), İstanbul: Global.

Baltac1, A. (2018). Nitel araştırmalarda örnekleme yöntemleri ve örnek hacmi sorunsalı üzerine kavramsal bir inceleme, Bitlis Eren Üniversitesi Sosyal Bilimler Enstitüsü Dergisi, S. 7 (1), ss. 231-274.

Bilgin, A. ve Oksal, A. (2018). Kültürel kimlik ve eğitim. Academy Journal of Educational Science, No. 2 (1), pp. 82-90.

Beşirli, H. (2010). Yemek, kültür ve kimlik. Millî Folklor, Y. 22. S. 87, ss. 159-169

Bourse, M. ve Yücel, H. (2017). Kültürel çalışmaları anlamak. (H. Yücel, Çev.). İstanbul: İletişim.

Bucak, A. ve Aracı Erdoğan, Ü. (2013). Türkiye'de gastronomi turizmi üzerine genel bir değerlendirme, Balıkesir Üniversitesi Sosyal Bilimler Enstitüsü Dergisi, (16. Cilt). S.30, ss.203-216.

Dalbay, R. S. (2018). Kimlik ve toplumsal kimlik kavramı. Süleyman Demirel Üniversitesi Sosyal Bilimler Enstitüsü Dergisi, S. 2 (31), ss. 161-176.

Duran, E. (2011). Turizm, kültür ve kimlik ilişkisi; turizmde toplumsal ve kültürel kimliğin sürdürülebilirliği, İstanbul Ticaret Üniversitesi Sosyal Bilimler Dergisi, Y11. 10. S.19 ss.291-313

Fırat, M. (2014). Yemeğin ideolojisi ya da ideolojinin yemeği: Kimlik bağlamında yemek kültürü. folklor/edebiyat, (20. cilt). S. 80, ss. 129-140.

Goode, J. (2005). Yemek. (F. Mormenekşe, Çev.). Milli Folklor. Y. 1, S. 67 ss. 172-176.

Göğebakan, Y. (2015). Dünya üzerindeki kültürel varlıkların turizme ve ekonomiye katkısı. Sanat \& Tasarım Dergisi, (5. Cilt). S. 2, ss.48-75.

Ichijo, A. ve Ranta, R. (2018). Yemek ve ulusal kimlik. İstanbul: Ayrıntı.

Karpat, K. (2010). Etnik yapılanma ve göçler. İstanbul: Timaş.

Kuzucu, K. (2006). Osmanlı döneminde Karadeniz bölgesinde mısır kullanımı ve mısır tarımını geliştirme çabaları. S. Ü. Fen Edebiyat Fakültesi Dergisi. S. 8 (2), ss. 113-126.

McCarthy, J. (1998). Ölüm ve sürgün, (B. Umar, Çev.). İstanbul: İnkılap.

Miles, B. M. ve Huberman, A. M. (1994). Qualitative data analysis: An expanded source book. California: Sage.

Öksüz Yolkolu, A. (2016). Hüzün aş olunca-geleneksel Çerkez mutfağı. İstanbul: Yediveren.

Öztek, U. (2019). Selim Illeri’nin eserlerinde yeme içme kültürü. Basılmamış Yüksek lisans Tezi. Hacettepe Üniversitesi Sosyal Bilimler Enstitüsü, Ankara.

Sönmez Selçuk, S. (2012). Dünden bugüne milliyetçilik küresel dünyada yükselen sesler. Anadolu Üniversitesi Sosyal Bilimler Dergisi, S. 2 (3), ss. 117-136.

Strauss, A. ve Corbin, J. (1990). Basics of qualitative research: grounded theory procedurs and techniques. California: Sage.

Süfer, Ö. ve Sezer Çelebi, Y. (2014). Bir Karadeniz klasiği: Kuymak. 4. Geleneksel Gıdalar Sempozyumu, Adana.

Ulugün, F. Y. (2015). Kocaeli'de tarihsel göçler. Uluslararası Gazi Akça Koca ve Kocaeli tarihi sempozyumu bildirileri. Kocaeli Büyükşehir Belediyesi, Kocaeli. 
Yıldırım, E. (2019). Yemek, ulusal kimlik ve milliyetçilik ilişkisi üzerine: "Çiya" markası ve "Turquality" programı örnekleri üzerinden bir yaklaşım denemesi, Ekonomi, Politika \& Finans Araştırmaları Dergisi, S. 4 (2), ss. 188-203.

Yıldırım, A. ve Şimşek, H. (2018). Sosyal bilimlerde nitel araştırma yöntemleri. Ankara: Seçkin.

Zeyrek, Y. (2001). Acaristan ve Acarlar. Ankara: Özel.

Wolcott, H. F. (1994). Transforming qualitative data: Description, analysis and interpretation. Newbury Park, CA: Sage.

\section{Elektronik kaynaklar}

Babaoğlu, M. (2019). Mısır tarımı. (Erişim: 09.09.2019) https://arastirma.tarimorman.gov.tr/ttae/sayfalar/detay.aspx? sayfaid $=89$

Cadi (Mısır ekmeği). (Erişim: 11.11.2019) http://kutluata.net/Aralik2011Koyumuz.aspx

Etnik grup. (Erişim: 09.09.2019) https://tr.wikipedia.org > wiki > Etnik_grup

Gürs, M. (2013). Yeni Anadolu mutfağl, İstanbul Yiyecek İçecek Grubu. (Erişim: 10.11.2019) https:// www.iyig.com.tr/tr/projeler/yeni-anadolu-mutfagi

Huseh, V. ve Chen, H. (2017). Key concepts in intercultural dialogue. (Erişim: 13.11.2019) https://centerforinterculturaldialogue.files.wordpress.com/2017/01/kc22-cultural-identity_turkish.pdf

Huvaj, N. (2005). Kültürel kimlik ve diaspora. (Erişim: 13.11.2019) https://www.kaffed.org/bilgi-belge/diaspora/item/277-kulturel-kimlik-ve-diaspora.html

Mıhlama görseli. (Erişim: 11.11.2019) https://yemek.com/tarif/rize-usulu-mihlama/

Şener, E. (2019). Karadeniz'den Ittalya 'ya mısır ekmeği, Gastrofest, 2 Ocak 2019 tarihli yazısı. Erişim: (09.09.2019) http://www.gastrofests.com/karadenizden-italyaya-misir-ekmegi/

Şipsi Paste görseli. (Erişim: 10.11.2019) https://ibikibik.tumblr.com/post/160299513762/ ak $\% \mathrm{C} 5 \% 9 \mathrm{Fam}-\% \mathrm{C} 3 \% \mathrm{BCst} \% \mathrm{C} 3 \% \mathrm{BC}-\mathrm{at} \% \mathrm{C} 4 \% \mathrm{~B} 1 \% \mathrm{C} 5 \% 9 \mathrm{Ft} \% \mathrm{C} 4 \% \mathrm{~B} 1 \mathrm{rmal} \% \mathrm{C} 4 \% \mathrm{~B} 1 \% \mathrm{C} 4 \% 9 \mathrm{~F} \%$ C4\%B1-mamis-ka\%C3\%A7amak-\%C5\%9FipsiŞipsi

Türkiye Kültür Portalı (2019). Mısır unu. Artvin. (Erişim: 30.07.2019) https://www.kulturportali.gov. tr/turkiye/artvin/nealinir/misir-unu 